\title{
The challenges of a school library in the digital age as a resource helping educating refugee children and integrating them into the Swedish society
}

\author{
Mr Per Johansson \\ School librarian \\ Spånga gymnasium and Spånga grundskola, \\ City of Stockholm \\ Sweden \\ per.g.johansson@stockholm.se
}

\begin{abstract}
Abstact
Approximately 163000 refugees came to Sweden in 2015, mainly from Afghanistan, Iraq, Syria and Somalia. Many of them were just children. These children have faced extreme dangers and endured extreme hardships but once in Sweden they receive a school education. A number of these children have been designated to schools in Spånga, in Stockholm, the capital of Sweden where I work. The absence of parents, language barriers, cultural differences, lack of earlier education along with other challenges must be acknowledged and addressed constructively in order for the school library to make a difference. A school library built for the digital age might give access to thousands of books, modern information technology, Internet and digital resources but it requires of its' users to be literate and to have digital literacy. Many of the children's language- and information and communication technology skills are poor and they are therefore not able to make good use of the school library without help. It requires of the professional school librarian to bridge over the gap.
\end{abstract}

Keywords: Digital literacy, Language literacy, Multicultural schools, Second language learners

\section{Introduction}

A Swedish school is a reflection of the Swedish society as a whole, and is undergoing a transformation to become multicultural and multilingual in every way. Large-scale adjustments are being made in public schools when receiving new arrivals and when including them into ordinary classes. The Curriculum for the Compulsory Schools states that: "The internationalisation of Swedish society and increasing cross-border mobility place high demands on the ability of people to live with and appreciate the values inherent in cultural diversity" (Curriculum, 2011, p.9). Schools have a big responsibility when fostering pupils how to do so. It is these very pupils whom are going to inhabit the multi-ethnic, multicultural, and multilingual Sweden of tomorrow.

Sweden's population is 9, 9 million inhabitants. From having had a largely homogeneous population for centuries with $100 \%$ of its population literate, Sweden has now developed to become a multicultural and multilingual nation with a most heterogeneous population of which not everyone is literate in the Swedish language. As people from many different countries have come to Sweden today many municipalities in Sweden have its' percentage of foreign origins (non-natives, and/or natives with both their parents originating from other countries) exceeding $40 \%$ of their total population (Statistiska centralbyrån, 2016). Estimates made in Stockholm (Stockholms stad, 2016a) one third of its' population, close to 300000 persons, have their origin in other countries. The existing variation within the multicultural, ethnic, religious, and linguistic heritage of the Swedish population is reflected in the society in many good ways, but also in the shapes of more segregated living communities, social 
inequalities and discrimination of non-native Swedish population in the labor market. In recent years the immigration has increased so that "in 2015 Sweden had the highest per capita inflow of asylum seekers ever to be registered in an OECD country creates particular challenges, according to the OECD" (Government Offices of Sweden, 2016). The society is changing in many ways.

According to The Swedish Agency of Migration (Migrationsverket) there are more than 170 000 people whom are registered as asylum seekers today, of which more than 140000 are waiting for a decision in their final asylum case.

Municipalities, government authorities and the rest of society are also facing challenges, regarding both the asylum seekers who are allowed to stay in Sweden and those whose applications are refused. The number of asylum cases appealed will rise in the coming years, as will the number of people who need to return. At the same time, society needs to create long-term conditions for the introduction of those who are allowed to stay in Sweden." (Migrationsverket, 2016a)

The effects in the Swedish society this large influx of refugees are causing have been lively debated. It has to a degree divided the population into those who advocates a continued reception of refugees and those who advocates a more restrictive reception of refugees. Regardless of the perspective, Sweden must live up to its' responsibilities to help refugees whom are already in the country. As schools are compelled by law to give every child living in Sweden an equal right to education, school libraries and school librarians can make a difference in this endeavor, if only adjusting their services accordingly.

\section{Background}

The UNHCR reports that three times as many people have crossed the Mediterranean Sea so far in 2016 as in the same period in 2015. The driving forces behind people seeking protection in Europe have not decreased (Migrationsverket, 2016a). The number of immigrants and refugees coming to Sweden has, as a whole increased somewhat over the last few decades but it sky rocketed dramatically during the last months in 2015.

\section{Persons seeking asylum 2010- May 2016}

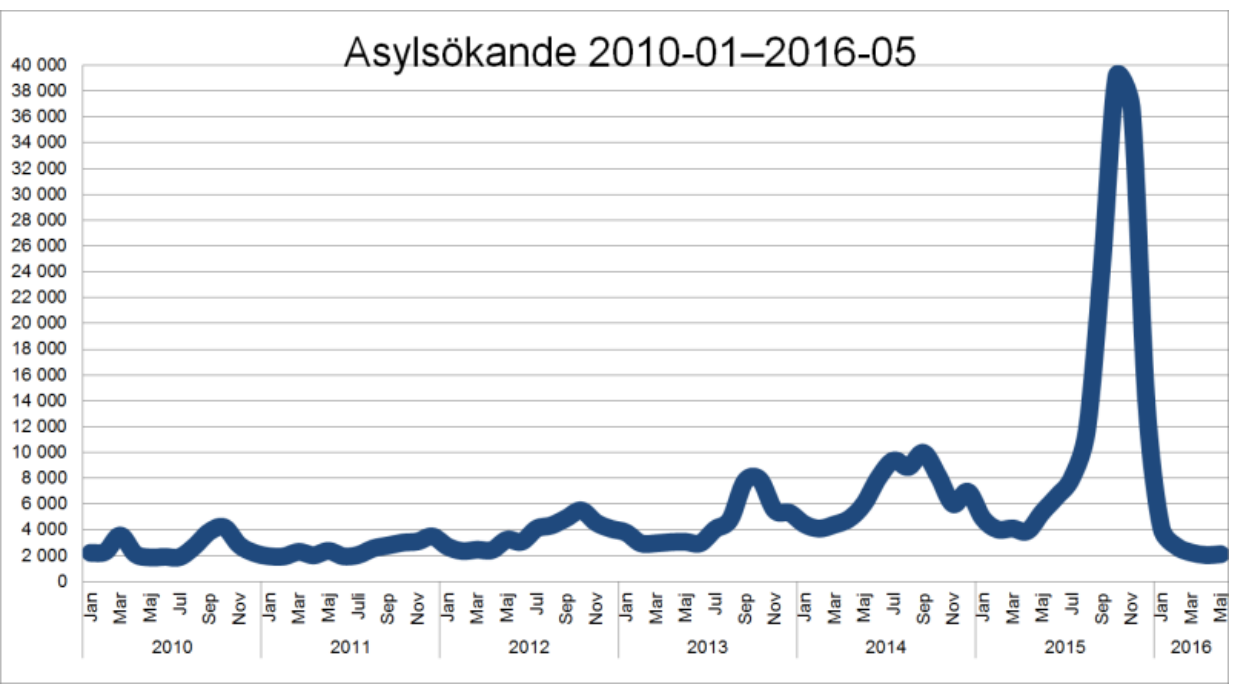

Source: Migrationsverket (2016d) 
Staggering 20000 so called "unaccompanied minors" alone, defined as children under the age of 18 unaccompanied by any of their parents or other adult relative, came to Sweden during the tree last months in 2015 (Migrationsverket, 2016b). The situation was becoming critical.

The national system of refugee reception soon became overheated, as the news reported on a daily basis, crashing down towards the end of 2015. From having its' borders open and welcoming all refugees, the border control of Sweden no longer functioned. The Swedish municipalities with a responsibility for receiving an ever increasing inflow of those seeking asylum, of which many were children, exhausted their resources. They were impelled to signal to the government that they could no longer receive any additional number. Their limit was reached and the government reluctantly enforced a stricter border control preventing any additional refugees from coming to Sweden. The number of refugees seeking asylum were close to 163000 in 2015 but has since then decreased, as reported by the Agency of Migration (Migrationsverket, 2016).

Last year was indeed dramatic. A total of 162877 persons were seeking asylum in Sweden (Migrationsverket, 2016c). 70384 of these persons were children under the age of 18. Out of the total number of children seeking asylum in Sweden in 2015, 40000 were in the ages of 13-17. 35369 out of the total of 70384 number of children were unaccompanied minors, of whom almost all were boys (only approximately 2000 out of 35000 were girls), in need of much special assistance from the municipalities and from public schools. The largest groups of children came from Afghanistan, Syria, followed by Somalia and Eretria (Migrationsverket, 2016c).

All children arrived to Sweden have been designated to schools becoming "new arrivals". A new arrival is defined as a pupil whom does not have, nor speak, Swedish as a mother language, arriving to Sweden after the age of 7 when supposed to be attending school already, and who has not attended school in Sweden for more than 4 years (Stockholms stad, 2016b).

\section{New arrivals in Stockholm}

The large number of immigrants and asylum seekers whom have come to Stockholm has made it difficult to find schools able to receive new arrivals. Most public schools in Stockholm are already full. The large number of new arrivals coming to Stockholm has therefore led to a real need for an increased overall school capacity (i e school facilities, teachers) as the children arriving may or may not have received primary, secondary level of education in their home countries.

The Swedish National Agency for Education, the central administrative authority for the public school system, is offering extensive support and all kinds of measures to schools receiving large quantities of new arrivals (Skolverket, 2016a). The Agency's support is foremost directed to teachers and is not directed to the difficulties school libraries and school librarians are experiencing. They are left fending for themselves when adapting to needs of these new arrivals.

Sweden, with its' proportionally small population, has taken on a real challenge when receiving and integrating these children whom are seeking asylum in Sweden, and public schools in Stockholm are going to play an important role in meeting this challenge to many of them.

\section{The schools in Spånga}

Spånga grundskola is a $7^{\text {th }}$ to $9^{\text {th }}$ grades compulsory school in Spånga in the suburbs of Stockholm. It has close to 500 pupils aged 13-15. The pupils are of different ethnic, religious and cultural background, although the majority of the pupils are of Swedish origin. New 
arrivals coming to the school have been included in regular classes and given studying guidance in their mother languages, but are otherwise studying on the same terms as the Swedish pupils although they have to learn Swedish too as they go along. When the number of new arrivals increased in the late 2015 , so called preparatory classes were formed in close to 50 compulsory schools in Stockholm. In the spring in 2016 a preparatory class (7-9NY) with 16 new arrivals aged 13-15 were formed at Spånga grundskola.

Spånga gymnasium is a second upper school with 600 pupils attending one out of the four programmes: Natural Resource Use Programme, Natural Science Programme, Business Management and Economics Programme and Language Introduction Programme. While the pupils in compulsory school are mostly of Swedish origin, many of the pupils in the upper secondary school are predominantly first, second or third generation immigrants originating from countries in the Middle East and Africa.

Language introduction is a programme intended for new arrivals not qualifying for the national programmes in upper secondary school. It is offered to young people ages 16-21 whom have recently arrived in Sweden, focusing on the Swedish language. Language introduction is adapted to each individual student and is supposed to lead to the new arrivals qualifying to entering a regular programme. It is planned on the basis of an assessment of the students' language skills carried out before reception. The new arrivals in Spånga gymnasium are divided into four classes according to their assessments - from beginners' level to a more advanced level of Swedish literacy.

\section{The school library}

The school library is equally charred between the 2 schools, their respective pupils intermixing in the library. It consists of two large former classrooms and is equipped with 60 study places. There are seven public computers with access to Internet, wifi is available for their own devices, and there is a printer and copy machine. The library is open 6 hours a day and is staffed with a full time employed school librarian. The printed collection is roughly estimated to 10000 titles, and the library subscribes to 20 newspapers and magazines. It is an environment encouraging to reading, talking, and socializing. The library is also making available a small number of licenced databases and other digital resources, such as accessing digital talking books for pupils with reading disabilities. The school library has earlier been participating in an e-book project together with five classes trying to read on tablets and computers.

The main and primary object of a school library is of course to support the school curriculum, and according to IFLA's School library guidelines the definition of a school library is:

- It has a qualified school librarian [ ] that enables the professional expertise required for the complex roles of instruction, reading and literacy development [ ].

- It provides targeted high-quality diverse collections (print, multimedia, digital) that support the school's formal and informal curriculum, including individual projects and personal development.

- It has an explicit policy and plan for ongoing growth and development.

School libraries, like other aspects of the educational system, go through phases of growth and development. However, these three features of a school library are necessary for the fulfilment of the mission and purpose of a school library. Research shows that the potential of a school library for having an impact on student learning is dependent on the extent to which these features are present in a school (IFLA, 2015, p.16-17).

\section{School librarian}


In Sweden, there is no legislation to make it compulsory to have an educated librarian attached to a school library. In many school libraries, the school librarian is even substituted by a teacher or an assistant, if having anyone at all. School librarians with an education both as a teacher and as a librarian, as in some other countries (e $\mathrm{g}$ teacher-librarians) are common in Sweden. I am fortunate to have both but am still not being able to use much of my skills due to the existing language barriers between myself and the new arrivals.

As a school librarian I have invited the preparatory class of new arrivals and new arrivals in the Language introduction programme classes to come to the school library, issuing them library cards and introducing them to the library facilities and the various school library resources. The purpose is not so much to get them to lend books or to use the computers, as to get them to familiarize themselves to the school library itself, to feel welcome, and to be able to explore the school library on their own. Although I try my best in Swedish as well as in English, the new arrivals usually don't understand much of what I say.

Not all of the new arrivals have had much of a school experience, their level of knowledge being lower than the average Swedish pupil, and they have had even less experience of having a school library. A challenge to me, as a school librarian, is therefore to transmit the very concept of a modern school library, and how they can make use of it. Traditional library services when advocating the school library, such as arranging library quizzes, reading advisory, book reviews, information retrieval lessons, etc. to new arrivals are difficult as the language barriers are wide. The usual ways of mediating literature and information literacy skills are not applicable at all in the case of new arrivals.

But a language is luckily made out of more than just written words. Voice, movement and natural body language (e g facial expressions) can be used to convey information, when communicating with the new arrivals. It is easily overlooked, but by being active, talkative and interacting with the new arrivals I can contribute to teaching them Swedish in a noncomplicated way without using any media. By purposely engaging them in conversations, however simple they might be, the new arrivals are given opportunities to practice speaking and comprehending Swedish when in the school library. If successfully creating a creative school library environment, the new arrivals will see the school library as a natural extension of their own classrooms, in which they are free to socialize with the other pupils in the two schools practicing Swedish on a daily basis.

To make the most out of the role as a school librarian, collaboration with the new arrivals teachers must be developed, working alongside each other when educating the new arrivals. This is a challenge since neither have the time to plan a sustainable collaboration.

\section{Print and digital school library collection}

One important school library function is to advocate reading. This is primarily done by making available a wide variety of media and information resources, and helping pupils to use appropriate media for their age, individual needs, personal interests and/or school assignments. Today, there are presently only sparsely printed media in languages other than Swedish or English in the school library collection. Since the new arrivals are engaged in very basic text book Swedish during classes, the demand for acquiring such media has been non-existing. They would simply not be able to read any of it most times.

A school library collection of printed media in foreign languages must however be organized, according to the guidelines for school libraries, as stated in the Library Act and the Education Act, since: "children and young adults and persons whom have another mother language than Swedish are considered to be priority groups and libraries are to access literature in other languages and easy to read-literature in Swedish to serve their needs" (SFS, Bibliotekslag, 2013, §5), and since "students in elementary school, school for students with 
intellectual disabilities, special school, Sami school, secondary school and upper secondary school for students with learning disabilities should have access to school libraries" (SFS, Skollag, 2010, 2 Kap §36).

Acquiring a collection of printed media, meeting the needs of new arrivals whom are speaking Arabic, Afghan Persian, Dari, Syriac, Somali, Turkish, Kurdish etc is never the less a real challenge to the school library, and must be done over time. Due to the language barriers, it is often difficult for me to purchase such media and integrate it into the school library collection compared to when purchasing media in Swedish or in English. Media in foreign languages is often notably more expensive than Swedish and English, as it is not in stock. The collection of literature in foreign languages is however about to be expanded and developed due to the arisen need to do so. Firstly known Swedish titles adapted to Arabic, Somali, etc., will be purchased. Children's books with illustrations intended for the age of 3-6, will also be purchased, as they are easy to read and can be most useful when learning a new language, even though the intended readers now are aged $13-21$ and not 3-6.

Although the new arrivals can't make any real use of the already existing collection of media, their proficiency in Swedish and English being insufficient, the school library can at least provide them with printed dictionaries in a various languages. These dictionaries are being well used expanding their vocabularies. In a way, it may be surprising that printed dictionaries are still at use at all, but keep in mind that not all pupils have access to computers or smart phones accessing online dictionaries. The new arrivals skills in how to use a computer or a smart phone are also often very limited.

The impact of reading on language development has been extensively investigated. Frequent reading correlates with positive development in various domains of language development, such as vocabulary growth, reading comprehension, decoding skills, spelling, grammatical knowledge and writing skills. One goal of the school library must therefore to be acquiring literature aimed for the very beginners which are easy to read.

"Easy-to-read books" in Swedish are a fast expanding literary genre, judging by the number of new titles being published every year. They are often contained to no more than 20-40 pages, and the disposition is in very short sentences. The genre was originally intended for mentally challenged persons and the childishly topics sometimes reflects just that in all its' simplicity. Some titles are ambitious and politically correct. The authors are trying hard to integrate the readers into the Swedish society, addressing gender inequalities, issues concerning sexualities, or putting forward the importance of learning the exact number of representatives in the Swedish parliament, hoping to make good democrats out of everyone. If recently arrived to Sweden, having escaping the horrors of the world, a child is not likely to be interested in just that.

In order to make new arrivals to read, not only for educational purposes, but for their pleasure as well, we must hope that authors will continue to contribute more creative topics to this genre, writing stories with more relevance to the new arrivals themselves. In the future, I am convinced that some great stories will derive from the writings of some of the new arrivals themselves.

\section{The extended library}

As the school library at Spånga grundskola and Spånga gymnasium can't manage to develop a collection in foreign languages all by itself, it requires some help in doing so. The International library (IB) in Stockholm is a special library within the municipal library. It has a collection of 200000 books and other media in more than 100 different languages. The library is staffed with multilingual librarians and they can assist school libraries acquiring multilingual media collections representing the languages spoken in a certain school providing expert help in doing so. School libraries can lend books or larger depositions of 
media in these languages, and in making them available to a school. This is a very efficient charred use of media. Purchasing guidance, information brochures, signs, library posters etc. in various languages can also be downloaded from the International library's web site for use in a school library.

Interestingly enough, during the spring in 2014 the International library sent out a survey to school libraries in the upper secondary schools to learn more about the challenges they were facing when attempting to make available media in foreign languages (Lucassi, 2014). More than $58 \%$ asked for guidance when choosing literature in other languages (e g book presentations and booklists). 52\% asked for purchasing guidance. $42 \%$ asked for training in learning in a multilingual environment. $29 \%$ asked for practical support (e g information materials and signs in different languages). These challenges, as seen above, may at a first glance seem to be at a very basic level of school librarianship, but the obstacles they represents are very real to any school librarian when not mastering languages needed and represents the very challenges I myself experience.

Listening to audiobooks can be an effective method when learning a new language but audiobooks intended to new arrivals in their teens are scarce, and the content in audiobooks for younger children are not always interesting enough to them. The Swedish Agency for Accessible Media (MTM) gives persons with reading impairments access to literature through streaming media. An estimated 100000 talking books in primarily Swedish and English are accessible via their web site and can easily be streamed to the users' smart phones or computers. School library staff administrates user logins to pupils in need of the service. Difficulties when reading Swedish as a foreign language, does not however count as a reading impairment, according to the legislation. The school library is therefore not allowed to offer this service to new arrivals, although it would certainly help them to learn Swedish more easily. Difficulties when reading in the mother language as well as in Swedish on the other hand entitles new arrivals to get access to talking books in Swedish as well as in other languages. Although teachers sometimes are questioning this inconvenience, it is important for me as a school librarian not to bypass any rule when giving access to talking books, as it would be damaging to the intended users of talking books (e g persons with reading impairment).

\section{Ongoing growth and development}

Today, the school library in which I work hasn't got any detailed plan for ongoing growth and development as of yet although some acquisition of media in some foreign languages will be made. The ever increasing number of new arrivals designated to the 2 schools of mine makes it important to address such an ongoing growth and development based on evaluations made of the school library of today. The International Federation of Library Association (IFLA) even emphasises in their guidelines that:

Evaluation is a critical aspect of an ongoing cycle of continuous improvement. Evaluation helps to align the library's programs and services with the goals of the school. Evaluation demonstrates to students and teachers, to library staff, and to the wider educational community the benefits derived from school library programs and services [---] Successful evaluation leads to renewal of programs and services, as well as development of new programs and services." (IFLA, 2015, p 8)

The school library, built for the digital age, is providing access to literature and information, printed as well as digital, and information and communication technology (ICT), Internet and various services retrieving and using information on an advances level, but it often requires of its' users to be literate in Swedish or English, and to have a basic understanding of modern ICT to be able to make use of such resources. Many of the new arrivals' languageand/or ICT skills are not as advanced in comparison to Swedish pupils, and they are not able 
to make use of the school library at all without extensive help. It requires a broader approach of me as the school librarian to develop strategies in collaboration with teachers targeting the groups of new arrivals, giving them the skills to be able to make use of the school library's resources and services themselves.

\section{Conclusion}

Sweden has received close to 170000 persons seeking asylum in 2015 alone. Approximately 70000 out of the total were children, designated to Swedish public schools. Today, Spånga grundskola and Spånga gymnasium, have close to 80 new arrivals attending the schools. The challenges of the school library and the school librarian are not being able to acquire media in their foreign languages, not being able to collaborate efficiently with teachers, and most of all not being able to communicate properly with the new arrivals as the language barriers are too wide. The new arrivals are furthermore most times not having a digital literacy developed enough to be able to use the school libraries digital resources and digital technology efficiently prohibiting them to access media and information.

The challenges to the 2 schools, to the school library itself and to the school librarian to adapt to the needs of the new arrivals are therefore considerable. This paper is a first step of an ongoing evaluation, as proclaimed by IFLA, mapping out the areas in which the school library can adapt to start contributing to the education of new arrivals and helping them to integrate into the Swedish society. It is clear that the role of the school library has to change. The traditional role of the school librarian also has to be challenged. A closer collaboration between school librarian and teachers must be developed as I, as a school librarian, am not able to communicate properly to the new arrivals.

It is also important to see all new arrivals as individuals, not clustering them together as one homogeneous group. Most of them are boys, some are girls. They are in different ages and they are coming from different cultures, social backgrounds, have different prior knowledge and are having different goals in life.

The school library's benefits from substituting traditional educational tools with ICT are not as big since the new arrival's digital literacy and a basic understanding of the Swedish language is poorly. The new arrivals are just not able to make effective use of ICT. Digital literacy training is however important if living in Sweden. ICT (e g audiobooks, e-books, Internet web sites, online dictionaries, data bases, Google translate) can enhance language knowledge as it offers more flexible ways of studying. It is also enhancing learning in general as it makes it possible for the new arrivals to produce and communicate information themselves, and not just passively receive and reproduce information as in traditional education. I can, as a school librarian, make a real difference when teaching new arrivals hands-on digital literacy empowering themselves in future learning. The understaffed school library with only one school librarian serving both schools will however not suffice if doing that. 


\section{References}

Curriculum for the compulsory school, preschool class and the recreation centre, 2011 (Lgr11) (2011), Stockholm: Skolverket.

Government Offices of Sweden (2016). OECD: Sweden on the right track to better introduction of new arrivals. Retrieved May 19, 2016, from

http://www.government.se/press-releases/2016/05/oecd-sweden-on-the-right-track-to-betterintroduction-of-new-arrivals/

IFLA International Federation of School librarianship (2015) School library guidelines, $2^{\text {nd }}$ ed. Barbara Schultz-Jones and Dianne Oberg (Eds.). Retrieved May 30, 2016, from http://www.ifla.org/files/assets/school-libraries-resource-centers/publications/ifla-schoollibrary-guidelines.pdf

Lucassi, Elin (2014). Skola + bibliotek = skolbibliotek. Att jobba mede mångspråkighet i skolbiblioteket. Kungliga biblioteket.

SFS, Skollag (2010:800). Retrieved May 21, 2016, from http://www.riksdagen.se/sv/dokument-lagar/dokument/svenskforfattningssamling/bibliotekslag-2013801 sfs-2013-801

SFS, Bibliotekslag (2013:801). Retrieved May 21, 2016, from http://www.riksdagen.se/sv/dokument-lagar/dokument/svenskforfattningssamling/bibliotekslag-2013801 sfs-2013-801

Statistiska centralbyrån (2016) Andel personer med utländsk bakgrund, 2015 jämfört med 2014. Retrieved May 17, 2016, from http://www.scb.se/sv /Hitta-statistik/Statistik-efter-amne/Befolkning/Befolkningenssammansattning/Befolkningsstatistik/25788/25795/Topplistor-kommuner/290738/

Skolverket (2016). Nyanlända elevers skolgång. Retrieved May 17, 2016, from http://www.skolverket.se/skolutveckling/larande/nyanlandas-larande

Stockholms stad (2016a). Statistik om Stockholm. Detaljerad statistik: Invånare med utländsk bakgrund, Hela staden per 31 dec 2015. Retrieved May 17, 2016, from http://statistik.stockholm.se/detaljerad-statistik

Stockholms stad (2016b). Pedagog Stockholm, Nyanlända. Retrieved May 20, 2016, from http://www.pedagogstockholm.se/nyanlanda/

Stockholms stad (2016c). Intranät. Lägesorientering flyktingmottagning i Stockholms stad. Retrieved May 11, 2016, from http://intranat.stockholm.se/Nyheter/2016/3/21/Lagesorientering-flyktingmottagning-iStockholms-stad/

Migrationsinfo.se. Ensamkommande barn. Retrieved May 17, 2016, from http://www.migrationsinfo.se/migration/sverige/asylsokande-i-sverige/ensamkommande-barn/

Migrationsverket. (2016a) Fewer asylum seekers are reaching Sweden, but society still faces major challenges. Retrieved May 20, 2016 from http://www.migrationsverket.se/English/About-the-Migration-Agency/News-archive/Newsarchive-2016/2016-05-09-Fewer-asylum-seekers-are-reaching-Sweden-but-society-stillfaces-major-challenges.html 
Migrationsverket (2016b) Statistik. Antal asylsökande ensamkommande barn 2014-mars 2016. Retrieved May 17, 2016, from

Source: http://www.migrationsverket.se/Andra-aktorer/Kommuner/Om-ensamkommandebarn-och-ungdomar/Statistik.html

Migrationsverket (2016c) Applications for asylum received, 2015. Retrieved May 20, 2016, from

http://www.migrationsverket.se/download/18.7c00d8e6143101d166d1aab/1451894593595/In

komna+ans\%C3\%B6kningar+om+asyl+2015+-+Applications+for+asylum+received+2015.pdf

Migrationsverket (2016d) Asylsökande. Retrieved June 1, 2016, from

http://www.migrationsverket.se/Om-Migrationsverket/Statistik/Asylsokande---de-storstalanderna.html

\section{Biographical note}

Per Johansson is 47 years old and is a school librarian with a M. Sc. in Library and Information Science from the University of Borås, Sweden. He has earlier worked as a school librarian in a K-9 school and more recently as a school librarian at Spånga grundskola (7-9) and Spånga gymnasium (10-12) since 2005. He likes to ride his motorcycle. 